\title{
PROFILE EVALUATION OF MEDICATION, COST COMPARISON, AND CLINICAL OUTCOME OF HUMAN AND ANALOGUE INSULIN TREATMENT TO TYPE-2 DIABETES MELLITUS OUTPATIENTS AT MEDISTRA HOSPITAL YEAR 2012-2013
}

\author{
Elisabeth Ninung Yuliarti ${ }^{1 *}$, Yusi Anggriani ${ }^{1}$, Dian Ratih Laksmitawati ${ }^{1}$, Prasasta Sutedjo ${ }^{1}$ \\ ${ }^{1}$ Faculty of Pharmacy, Pancasila University, DKI Jakarta, Indonesia \\ *Correspondence email: elisabethninung@gmail.com
}

\begin{abstract}
Two insulin types existing in the market are human and analog insulin, of which the human insulin is cheaper than that of analog. Despite such price disparity, the insulin analog in 2012-2017 is administered to patients more than human insulin. Medical practitioners at Medistra Hospital have no longer prescribed human insulin since 2014. This research's objectives were to evaluate the medication profile, compare cost profile, and clinical outcome of providing information for decision-makers to determine insulin administration policy in hospitals. The research subjects were type- 2 diabetes mellitus (T2D) outpatients at Medistra Hospital. The data collection was conducted retrospectively, taking samples of 121 outpatients, of which 83 outpatients were evaluated for their clinical outcome. The medication profile data were collected from the medicine administration at the Hospital Pharmacy Installation. The clinical outcome data, such as fasting plasma glucose (FPG), two-hour postprandial plasma glucose (2HPP), and Hemoglobin A1c (HbA1c), were garnered from the patients' medical records. The cost data were collected from the outpatients' payment receipts provided by the Hospital's Financial Department. Kolmogorov Smirnov normality test was applied in this research. The single human insulin's clinical outcome resulted in FPG as much as $115 \pm 6.52$, 2HPP as much as $176 \pm 4.43$, and $\mathrm{HbA} 1 \mathrm{c}$ as much as $7.63 \pm 0.47$. Meanwhile, the clinical outcome of single analog insulin resulted in FPG as much as $108 \pm 13.19,2 \mathrm{HPP}$ as much as $159 \pm 19.93$, and HbA1c as much as $6.61 \pm 1.28$. Kruskal Wallis Test was applied to find a statistical difference between the clinical outcome and the cost. The research result suggests that after Mann Whitney Test, the human and analog insulin were not significantly different seen from the clinical outcome result showing FPG ( $p=0.676), 2$ HPP $(\mathrm{p}=0.175), \mathrm{HbA} 1 \mathrm{c}(\mathrm{p}=0.0445)$, and from the cost result $(\mathrm{p}=0.795)$. Furthermore, the research also shows that the average cost of 30-day medication of single human insulin was Rp3,190,997.43, while one of analog insulin was Rp3,188,832.35. In conclusion, the study finds out that human and analog insulin were not significantly different if seen from the cost $(\mathrm{p}=0.795)$.
\end{abstract}

Keywords: Analogue Insulin; Diabetes Mellitus; Human Insulin

\section{INTRODUCTION}

Diabetes mellitus (thereafter called DM) is a chronic disease caused by the pancreas' insufficient insulin, which eventually increases the glucose concentration in blood and, consequently, such high concentration damages many-body systems, particularly blood vessels and nerve system (1). According to the International Diabetes Foundation, the number of DM patients worldwide reached 371 million, with 4.6 million mortalities (2). World Health Organization (WHO) predicted that the number of DM patients in Indonesia would increase from 8.4 million in 2000 to 21.3 million in 2030 (3). The data in 2014 showed that the number of DM patients in Indonesia reached 422 million, indicating a significant increase if compared to 108 million in 1980 (4). The prevalence of diabetes mellitus in adult patients in the world had doubled since 1980 , rising from $4.7 \%$ to $8.5 \%$ (5), showing that there was an increase in related-risk 
factors, such as body weight or obesity. Over the last few years, the prevalence of DM has increased more rapidly in low-income countries than in high-income ones (4).

Diabetes Mellitus is categorized into two types, they are Type-1 Diabetes Mellitus (T1D), also called insulin-dependent DM (IDDM), caused by the insufficient insulin secretion produced by beta-cell pancreas, and Type-2 Diabetes Mellitus (T2D), also called non-insulin-dependent DM (NIDDM), caused by the decrease of target tissue sensitivity to the insulin (6). The objectives of DM therapy is to reduce the symptoms of hyperglycemia complication, such as retinopathy, nephropathy, neuropathy, and to increase the quality and quantity of patients' lives. Worsening conditions to DM patients might happen due to their blood sugar instability. Diabetes might also cause complications such as hypertension, heart attack, and kidney failure (7). Indonesia Endocrinologists' Association (PERKENI, Perhimpunan Endokrinologi Indonesia) suggested that early therapy for DM patients should be administered orally. However, if the treatment of three oral medication combination has been done, insulin therapy should be carried out. Insulin therapy can be directly administered to DM patients if their condition's laboratory data show $\mathrm{HbA} 1 \mathrm{c} \geq 10 \%$ or $\mathrm{FPG} \geq 300 \mathrm{mg} / \mathrm{dl}$ with metabolic disorders (8). At present, the choices of therapy available, among others, are biguanides medication, sulfonylurea, pioglitazone, alpha-glucosidase inhibitors, GLP-1 receptor agonists, and insulin (6). Most Type-2 DM patients do not require insulin therapy. However, almost $30 \%$ of DM patients need insulin therapy in addition to oral hypoglycemic therapy (9).

Insulin is a vital medication for millions of Type-2 DM patients and a hundred million more. For more than a hundred years, insulin has been used for clinical therapy, but its availability is far from expectation (10). Based on its production method, there are two types of insulin, namely, analog and human insulin. Human insulin is taken from humans or made of synthetically resembling human amino-acid chain utilizing biosynthetic technology of DNA recombinant using bacteria or modified semisynthetic of porcine insulin (11). Analog insulin is produced using DNA recombinant technology to achieve a better absorption effect and longer therapy duration (12). Analog insulin is amino-acid insulin modified to give a rapid and more durable glucose reduction effect than human insulin (12). Human and analog insulin is comparably safer than inventors' products (natural animal insulin) (13). This safety is related to the purification process and hypoglycemia side-effect induced by natural animal insulin. However, it is found, in some cases, that human insulin might also cause hypoglycemia side-effects. This is because the maximum serum concentration (Cmax) in blood for human insulin is longer than the analog one (14).

Human and analog insulin have similar efficacy in reducing glucose levels. Nevertheless, it was found that the use of human insulin in hypoglycemia cases was lower than the analog insulin (15). The use of human or analog insulin calculated its safety risk. Some research found an increased risk of cancer in the use of glargine insulin (16) (17), although, in some other research, it was refuted that there was no strong evidence of cancer risk increase in the use of analog insulin.

According to an article in the National Institute of Clinical Excellence (NICE), human insulin is recommended more than analog insulin. The analog insulin is recommended for DM patients who cannot perform human insulin self-injection and those who suffer from hypoglycemia. Analog insulin may reduce the injection frequency due to its longer durability than human insulin. However, it was found that the analog insulin's effectiveness with long onset time was not significantly different from human insulin (19). Many countries have heavily invested in health budgets to ensure the use of analog insulin to be as effective as human insulin.

Insulin is a medication vital for DM patient therapy and is included in the shortlist of drugs covered by health insurance in many 
countries (21). In Indonesia, insulin was listed as a medication covered by National Health Insurance (JKN, Jaminan Kesehatan Nasional). According to the Ministry of Health in 2015, DM was one of the ten major diseases that had absorbed $33 \%$ of the total budget, as much as 3.27 trillion rupiahs. The budget covered the patients diagnosed with diabetes, diabetes with complications, and diabetes as comorbidities (22). Doctors' role in choosing the types of insulin therapy determined the degree to which JKN covered the treatment cost. Medistra Hospital is one of the private hospitals not collaborating with JKN so that the patients must pay for themselves or rely on their private insurance. Private insurance companies, however, only pay the claim once per month.

DM was one of the 5 most diseases suffered by patients treated in Medistra Hospital. The number of HbA1c increased every year. In Medistra Hospital, the type of insulin available was an analog one. The use of human insulin was reportedly decreasing. Since 2014, human insulin had not been prescribed by the doctors in Medistra Hospital.

The price of analog insulin in Medistra Hospital was reportedly higher than human insulin. A patient without health insurance using analog insulin therapy routinely would likely spend more money, which eventually impacted the increasing cost of the patient's treatment. This was where the research entitled "Profile Evaluation of Medication, Cost Comparison, and Clinical Outcome of Human and Analogue Insulin Treatment to Type-2 Diabetes Mellitus Outpatients at Medistra Hospital" found its rationale.

\section{RESEARCH METHOD}

The research was conducted as a longitudinal time series. The research data were collected from January 2012 to December 2013. The data were collected retrospectively from the patients' medical records, particularly the patients treated using human and analog insulin. The data were garnered in medication profile, clinical outcome (FPG, 2HPP, and HBA1c), medication cost, and the outpatients' financial records during their medical treatment. The data garnered were qualitatively and quantitatively analyzed. The sampling method applied was total sampling. The data were taken from the outpatients' medical records, medication from pharmacy installation, and cost from outpatients' administration unit.

Variables in the research are as follows:

a. Free (independent) variables: human and analog insulin

b. Dependent variables: medication profile, medication cost, clinical outcome.

The population comprises all Type- 2 DM outpatients covered by private health insurance and personal payment from January 2012 to December 2013.

Based on the patients' medical records, the research population was 176 Type- 2 DM outpatients using human and analog insulin. Applying Kriejcie-Morgan, the research found data sampling as many as 121 patients.

The patients were selected based on the following criteria:

1. Inclusion criteria

a. Outpatients diagnosed as Type-2 DM from January 2012-December 2013

b. Type-2 DM outpatients with insulin therapy having a routine control from January 2012 to December 2013

c. Outpatients having insulin therapy for at least 3 (three) times

2. Exclusion criteria:

Outpatients diagnosed as Type-2 DM from January 2012-December 2013, but having the following shortcomings:

a. Incomplete laboratory data

b. Incomplete medication data

c. Not treated with insulin

d. Incomplete cost medication

\section{RESEARCH FINDINGS}

Profile evaluation of the patients can be found in the demography data.

From the total sample of Type-2 DM outpatients using insulin, 121 patients were taken as the research subjects. 
Table 1. The demography of type-2 DM outpatients using human insulin, analog insulin, and combined insulin (human and analog) at Medistra Hospital

\begin{tabular}{|c|c|c|c|c|c|c|c|}
\hline \multirow[t]{2}{*}{ No } & \multirow[t]{2}{*}{ VARIABLE } & \multicolumn{2}{|c|}{ Human Insulin } & \multicolumn{2}{|c|}{ Analogue Insulin } & \multicolumn{2}{|c|}{$\begin{array}{l}\text { Combined Insulin } \\
\text { (Human and } \\
\text { Analogue) }\end{array}$} \\
\hline & & $\mathrm{N}$ & $\%$ & $\mathrm{~N}$ & $\%$ & $\mathrm{~N}$ & $\%$ \\
\hline \multirow[t]{3}{*}{1} & SEX & & & & & & \\
\hline & a. Malc & 21 & $48.84 \%$ & 34 & $48.57 \%$ & 10 & $45.45 \%$ \\
\hline & b. Female & 22 & $51.16 \%$ & 36 & $51.43 \%$ & 12 & $54.55 \%$ \\
\hline \multirow[t]{8}{*}{2} & AGE (ycars old) & & & & & & \\
\hline & a. $19-24$ & 0 & $0.00 \%$ & 0 & $0.00 \%$ & 0 & $0.00 \%$ \\
\hline & b. $25-34$ & 0 & $0.00 \%$ & 0 & $0.00 \%$ & 0 & $0.00 \%$ \\
\hline & c. $35-44$ & 4 & $9.30 \%$ & 3 & $4.29 \%$ & 1 & $4.55 \%$ \\
\hline & d. $45-54$ & 13 & $30.23 \%$ & 18 & $25,71 \%$ & 8 & $36.36 \%$ \\
\hline & e. $55-64$ & 16 & $37.21 \%$ & 28 & $40.00 \%$ & 10 & $45.45 \%$ \\
\hline & f. $65-74$ & 7 & $16.28 \%$ & 15 & $21.43 \%$ & 2 & $9.09 \%$ \\
\hline & g. $\geq 75$ & 3 & $6.98 \%$ & 6 & $8.57 \%$ & 1 & $4.55 \%$ \\
\hline \multirow[t]{11}{*}{3} & DIAGNOSIS & & & & & & \\
\hline & $\begin{array}{l}\text { a. E11.0 (Non-Insulin-Dependent } \\
\text { DM with Coma) }\end{array}$ & 0 & $0.00 \%$ & 0 & $0.00 \%$ & 0 & $0.00 \%$ \\
\hline & $\begin{array}{l}\text { b. E11.1 (Non-Insulin-Dependent } \\
\text { DM with Ketoacidosis) }\end{array}$ & 0 & $0.00 \%$ & 0 & $0.00 \%$ & 0 & $0.00 \%$ \\
\hline & $\begin{array}{l}\text { c. E11.2 (Non-Insulin-Dependent } \\
\text { DM with Renal Complication }\end{array}$ & 3 & $6.98 \%$ & 6 & $8.57 \%$ & 3 & $13.64 \%$ \\
\hline & $\begin{array}{l}\text { d. E11.3 (Non-Insulin-Dependent } \\
\text { with Ophthallnic } \\
\text { Complications) } \\
\end{array}$ & 0 & $0.00 \%$ & 0 & $0.00 \%$ & 0 & $0.00 \%$ \\
\hline & $\begin{array}{l}\text { e. E11.4 (Non-Insulin-Dependent } \\
\text { DM with Neurological } \\
\text { Complications) }\end{array}$ & 3 & $6.98 \%$ & 4 & $5.71 \%$ & 1 & $4.55 \%$ \\
\hline & $\begin{array}{l}\text { f. E11.5 (Non-Insulin -Dependent } \\
\text { DM with Peripheral) }\end{array}$ & 1 & $2.33 \%$ & 1 & $1.43 \%$ & 0 & $0.00 \%$ \\
\hline & $\begin{array}{l}\text { g. E11.6 (Non-Insulin Dependent } \\
\text { DM with Other Spccificd } \\
\text { Complications) }\end{array}$ & 0 & $0.00 \%$ & 0 & $0.00 \%$ & 0 & $0.00 \%$ \\
\hline & $\begin{array}{l}\text { h. E11.7 (Non-Insulin-Dependent } \\
\text { DM with Multiple } \\
\text { Complication }\end{array}$ & 0 & $0.00 \%$ & 0 & $0.00 \%$ & 0 & $0.00 \%$ \\
\hline & $\begin{array}{ll}\text { i. } & \text { E11.8 (Non-Insulin-Dependent } \\
\text { DM with Cnspecificd } \\
\text { Complications) } \\
\end{array}$ & 0 & $0.00 \%$ & 0 & $0.00 \%$ & 0 & $0.00 \%$ \\
\hline & $\begin{array}{l}\text { j. E11.9 (Non-Insulin-Dependent } \\
\text { DM without Complication) }\end{array}$ & 36 & $83.72 \%$ & 55 & $78.57 \%$ & 18 & $81,82 \%$ \\
\hline \multirow[t]{4}{*}{4} & EDUCATION BACKGROLND & & & & & & \\
\hline & a. Senior High School & 4 & $9.30 \%$ & 4 & $5.71 \%$ & 2 & $9.09 \%$ \\
\hline & b. Associate Degree level 1 & 0 & $0.00 \%$ & 2 & $2.86 \%$ & 0 & $0.00 \%$ \\
\hline & c. Associate Degree level 2 & 0 & $0.00 \%$ & 0 & $0.00 \%$ & 0 & $0.00 \%$ \\
\hline
\end{tabular}

\begin{tabular}{|c|c|c|c|c|c|c|c|}
\hline \multirow[t]{2}{*}{ No } & \multirow[t]{2}{*}{ VARIABLE } & \multicolumn{2}{|c|}{ Human Insulin } & \multicolumn{2}{|c|}{ Analoguc Insulin } & \multicolumn{2}{|c|}{$\begin{array}{c}\text { Combined Insulin } \\
\text { (Human and } \\
\text { Analogue) }\end{array}$} \\
\hline & & $\mathrm{N}$ & $\%$ & $\mathrm{~N}$ & $\%$ & $\mathrm{~N}$ & $\%$ \\
\hline & d. Associate Degrec level 3 & 6 & $13.95 \%$ & 5 & $7.14 \%$ & 3 & $13.64 \%$ \\
\hline & c. Bachclor Degrec & 13 & $30.23 \%$ & 55 & $78.57 \%$ & 18 & $81.82 \%$ \\
\hline & i. Masier Degree & 0 & $0.00 \%$ & 3 & $4.29 \%$ & 0 & $0.00 \%$ \\
\hline \multirow[t]{5}{*}{5} & OCCUPATION & & & & & & \\
\hline & 1. Wilc Housc & 5 & $11.63 \%$ & 6 & $8.57 \%$ & 2 & $9.09 \%$ \\
\hline & 2. Civil Servant & 4 & $9.30 \%$ & 2 & $2.86 \%$ & 3 & $13.64 \%$ \\
\hline & 3. Privalc & 33 & $76.74 \%$ & 56 & $80.00 \%$ & 16 & $72.73 \%$ \\
\hline & 4. Retired & 1 & $2.33 \%$ & 5 & $7.14 \%$ & 1 & $4.55 \%$ \\
\hline \multirow[t]{3}{*}{6} & SMOKING HABIT & & & & & & \\
\hline & 1. Smoking & 3 & $6.98 \%$ & 14 & $20.00 \%$ & 3 & $13.64 \%$ \\
\hline & 2. Non-Smoking & 40 & $93.02 \%$ & 56 & $80.00 \%$ & 19 & $86.36 \%$ \\
\hline \multirow[t]{3}{*}{7} & DRINKING HABIT & 0 & $0.00 \%$ & 0 & $0.00 \%$ & 0 & $0.00 \%$ \\
\hline & 1. Non-Alcoholic & 43 & $\begin{array}{c}100.00 \\
\%\end{array}$ & 70 & $100.00 \%$ & 22 & $100.00 \%$ \\
\hline & 2. Alcoholic & 0 & $0.00 \%$ & 0 & $0.00 \%$ & 0 & $0.00 \%$ \\
\hline \multirow[t]{11}{*}{8} & COMORBIDITIES & & & & & & \\
\hline & 1. Without comorbiditics & 0 & $0.00 \%$ & 0 & $0.00 \%$ & 0 & $0.00 \%$ \\
\hline & 2. Hypertension & () & $0.00 \%$ & 0 & $0.00 \%$ & 0 & $0.00 \%$ \\
\hline & a. Hypcrtcusion & 0 & $0.00 \%$ & 2 & $2.86 \%$ & 0 & $0.00 \%$ \\
\hline & b. Hypertension +1 comorbidities & 13 & $30.23 \%$ & 16 & $22.86 \%$ & 0 & $0.00 \%$ \\
\hline & c. Hypericnsion +2 comorbidities & 20 & $46.51 \%$ & 9 & $12.86 \%$ & 1 & $4.55 \%$ \\
\hline & d. Hypertcnsion +3 comorbiditics & 1 & $2.33 \%$ & 0 & $0.00 \%$ & 0 & $0.00 \%$ \\
\hline & $\begin{array}{l}\text { 3. Comorbidities non- } \\
\text { Hypertension }\end{array}$ & 0 & $0.00 \%$ & 0 & $0.00 \%$ & 0 & $0.00 \%$ \\
\hline & a. 1 Comorbidities & 2 & $4.65 \%$ & 1 & $1.43 \%$ & 0 & $0.00 \%$ \\
\hline & b. 2 comorbidities & 4 & $9.30 \%$ & 4 & $5.71 \%$ & 1 & $4.55 \%$ \\
\hline & c. 3 comorbiditics & 0 & $0.00 \%$ & 0 & $0.00 \%$ & 0 & $0.00 \%$ \\
\hline \multirow[t]{8}{*}{9} & COMPLICATIONS OF DM & & & & & & \\
\hline & 1. Neuropatthy DM & 3 & $6.98 \%$ & 7 & $10.00 \%$ & 0 & $0.00 \%$ \\
\hline & 2. Neuropathy DM + Cataracts & () & $0.00 \%$ & 0 & $0.00 \%$ & 0 & $0.00 \%$ \\
\hline & 3. Neuropathy DM + Gangrence & 1 & $2.33 \%$ & 0 & $0.00 \%$ & 1 & $4.55 \%$ \\
\hline & 4. Calaracis & 0 & $0.00 \%$ & 0 & $0.00 \%$ & 0 & $0.00 \%$ \\
\hline & 5. Gangrene & () & $0.00 \%$ & 0 & $0.00 \%$ & 0 & $0.00 \%$ \\
\hline & 6. Nephropathy DM & 3 & $6.98 \%$ & 8 & $11.43 \%$ & 3 & $13.64 \%$ \\
\hline & 7. Withoul complications & 36 & $83.72 \%$ & 55 & $78.57 \%$ & 18 & $81.82 \%$ \\
\hline \multirow[t]{2}{*}{10} & HYPOGLYCEMIA & & & & & & \\
\hline & Hypoglycemia & 1 & $2.33 \%$ & 0 & $0.00 \%$ & 1 & $4.55 \%$ \\
\hline \multirow[t]{2}{*}{11} & PAYMENT METHOD & 0 & $0.00 \%$ & 0 & $0.00 \%$ & 0 & $0.00 \%$ \\
\hline & 1. Self-Funding & 35 & $81.40 \%$ & 27 & $38.57 \%$ & 17 & $77.27 \%$ \\
\hline
\end{tabular}

\begin{tabular}{|c|c|c|c|c|c|c|c|}
\hline \multirow[t]{2}{*}{ No } & \multirow[t]{2}{*}{ VARTABLE } & \multicolumn{2}{|c|}{ Human Insulin } & \multicolumn{2}{|c|}{ Analoguc Insulin } & \multicolumn{2}{|c|}{$\begin{array}{l}\text { Combined Insulin } \\
\text { (Human and } \\
\text { Analogue) }\end{array}$} \\
\hline & & $\mathrm{N}$ & $\%$ & $\mathrm{~N}$ & $\%$ & $\mathrm{~N}$ & $\%$ \\
\hline & 2. Privalc Insurance & 3 & $6.98 \%$ & 11 & $15.71 \%$ & 13 & $59.09 \%$ \\
\hline \multirow[t]{6}{*}{12} & OUTPATIENTS VISITS & & & & & & \\
\hline & a. Visits $<3$ times & 0 & $0,00 \%$ & () & $0.00 \%$ & 0 & $0.00 \%$ \\
\hline & b. Visits 3-5 timcs & 19 & $44.19 \%$ & 30 & $42.86 \%$ & 11 & $50.00 \%$ \\
\hline & c. Visits 6-8 times & 23 & $53.49 \%$ & 39 & $55.71 \%$ & 10 & $45.45 \%$ \\
\hline & d. Visits 9-11 times & 1 & $2.33 \%$ & 1 & $1.43 \%$ & 1 & $4.55 \%$ \\
\hline & c. Visits $\geq 12$ times & 0 & $0.00 \%$ & 0 & $0.00 \%$ & 0 & $0.00 \%$ \\
\hline \multirow[t]{3}{*}{13} & PATILNTS ADMITTANCE & & & & & & \\
\hline & a. Polyclinic & 39 & $90.70 \%$ & 52 & $74.29 \%$ & 20 & $90.91 \%$ \\
\hline & b. ER & 4 & $9.30 \%$ & 18 & $25,71 \%$ & 2 & $9.09 \%$ \\
\hline \multirow[t]{3}{*}{14} & PATIENT STATLS & & & & & & \\
\hline & a. Married & 41 & $95.35 \%$ & 70 & $100.00 \%$ & 22 & $100.00 \%$ \\
\hline & b. Singlc & 2 & $4.65 \%$ & () & $0.00 \%$ & 0 & $0.00 \%$ \\
\hline
\end{tabular}

According to Rahmi Yosmar and Agus the number of women who have diabetes was higher than men, which is $36: 35$. The subjects of the research in this study were mostly female, although the difference was not significant. Women are perilous to suffer from DM than men. This is because the LowDensity Lipoprotein (LDL) or triglycerides in women is higher than men. Type-2 diabetes is primarily due to females' and males' different activities and lifestyles, affecting the disease. These are the factors that cause diabetes mellitus (37).

The age of the subjects of the research ranged from 55 to 64 years old. The data were 
supported by Kusnanto' research stating that the respondents taken in his research ranged from 45-65 years old.

According to table V.3, most Type-2 DM patients at Medistra Hospital were categorized into Non-Insulin Dependent Without Complication. However, the high complication caused by diabetes mellitus was neuropathy. The data of infectious disease control released by the Ministry of Health stated that the high percentage of complications caused by diabetes mellitus at Cipto Mangunkusumo Hospital was neuropathy (39). The present study is similar to Muthiah's, stating that neuropathy was likely to be found in DM patients around 55 years old (40).

The research showed that $90.8 \%$ of DM outpatients came to a polyclinic before commencing their further treatment to the hospital. This indicated that most patients were not admitted through the Emergency Room.

The research showed that the high number of type-2 DM outpatients based on education level was bachelor's degree students. This is supported by the RISKESDAS (Basic Health Research) 2018, stating that the highest prevalence of DM patients based on education level was associate degree level 1, level 2, level 3, and university students.

The number of smoking patients was more than non-smoking ones. Smoking habit may worsen the DM because nicotine can release insulin due to the catecholamine hormone activity that prevents the work of betta cells of the pancreas and causes insulin resistance (41). Maria Redita, in her research, explained that there was a weak yet significant relationship between the length of smoking and the increased glucose level. This is due to the fact that nicotine exposure increased mTOR activity and IRS-1 Ser636 Phosphorylation, which eventually caused the resistance of insulin receptors and insulin secretion dysfunction. All the patients in this research were not alcoholics.

The most comorbidities suffered by the patients in this research were hypertension and one other disease. The number and the types of comorbidities of type-2 DM patients might affect the amount and types of non-DM medication consumed by the patients. The hospital visits frequency of the patients to be taken as the sample was 6-8 times.

The number of hypoglycemic cases in 2012 was 2. They are the uses of human insulin and the combination of human and analog insulin.

The marital status of type- 2 diabetes patients in 2012 and 2013 taken in this research were married. This is supported by Kusnanto's research stating that the highest percentage of the respondents' marital status in his research was married (38).

\section{Treatment Profile}

1. The number of medication

a. The average number of medications per patient

The average number of medication items was obtained from the medication consumed by the type- 2 DM patients in 2012 and 2013 at Medistra hospital. The average number of medications per patient was 2 DM medication, three non-DM medication, and 1 medical tool item. Firni et al. stated that based on the data of DM medication use in 2014, there were four or more medications with 3OAD composition and insulin (43). Some samples showed that the more medication items were consumed, the more patients with comorbidities were. However, some other samples showed that the comparison of the total number of medication items was not directly proportional to comorbidities. This is because doctors prescribed supplements as an additional therapy to the type-2 DM outpatients.

2. DM and Non-DM Medication Proportion

Diabetes mellitus medication is a drug used for therapy purposes, while the non-DM medication is for other diseases suffered by DM patients. The patients' average of DM medication consumed was $35.45 \%$, while non-DM medicine was $64.55 \%$. The patients' DM medication items were 2 items, while the non-DM medications were 3 items. This showed that the use of non-DM medication 
type was more than that of the DM one. This is due to the patients' comorbidities and the additional supplement prescribed for type-2 DM patients. The OAD group most frequently used in this research, 50\%, was biguanides with Glucophage 500 mg's trademark.

\section{Insulin use proportion}

a. Prescription of insulin based on the insulin types

The most prescribed insulin types in 2012 were single-human insulin, while the most prescribed insulin types in 2013 were the combination of analog and human insulin.

b. Prescription of insulin types based on the durability

In 2012 the type of insulin most frequently used was the short-acting human insulin group. Meanwhile, in 2013 the most frequently used insulin type was the combination of long-acting and rapid-acting analog insulin groups.

\section{Clinical Outcome}

Single analog insulin resulted in a better clinical outcome with fasting plasma glucose (FPG) of 108, which was considered exceptionally low. The better value of the clinical outcome for two-hour postprandial plasma glucose (2HPP) was combined-analog insulin and the oral antidiabetic drug (OAD) with the lowest 2HPP of 166 . The better clinical outcome result for $\mathrm{HbA} 1 \mathrm{c}$ was singleanalog insulin with an HbA1c of 6.61, which was considered exceptionally low. Compared to single-human insulin, the single-analog insulin resulted in a better clinical outcome for FPG, 2HPP, and HbAlc. The data can be found in table V.14. Meanwhile, the combination of analogs insulin resulted in a better outcome for FPG, 2HPP, and HbAlc than the combination of human-analog insulin. However, the combination of analog insulin and OAD shows a better result than the combination of human insulin and OAD.

After the clinical outcome for each insulin type was calculated, the KruskalWallis statistic test was conducted to ensure there were differences in statistics.
Based on the Kruskal-Wallis table test, it was found that for the type-2 DM outpatients at Medistra Hospital in 2012-2013, the FPG difference between insulin types was 67.594 with a probability value ( $\mathrm{p}$-value) of 0.000 . Since the $p$-value was $0.000<\alpha$ value $=0.05$, $\mathrm{H}_{0}$ hypothesis was rejected. This study showed significant differences in the average of FPG between insulin types (at least there was one significantly different insulin group). The FPG test showed that the combined insulin consisting of analog insulin and OAD produced a better result of 194.33.

The research found that for outpatients at Medistra Hospital in 2012-2013, the 2HPP discrimination test between insulin types using the Kruskal-Wallis test was 66.780 with a p-value of 0.000 . Since the p-value was $0.000<\alpha$ value $=0.05, \mathrm{H}_{0}$ hypothesis was rejected. This study showed significant differences in the average of 2HPP between insulin types (at least there was one significantly different insulin group). The 2HPP test showed that the combined insulin consisting of analog insulin and OAD produced a better result of 198.82 .

For the type-2 DM outpatients at Medistra Hospital in 2012-2013, it was found that based on the Kruskal-Wallis test, the difference of $\mathrm{HbA} 1 \mathrm{c}$ between insulin types was 25.806 with the p-value of 0.000 . Since the p-value was $0.000<\alpha$ value $=0.05, \mathrm{H}_{0}$ hypothesis was rejected. This study showed significant differences in the average of HbA1c between insulin types (at least there was one significantly different insulin group). The HbA1c test result showed the best different outcome between the combined insulin consisting of single analog insulin with a value of 62.47 .

After the Kruskal-Wallis test showed a different result, the Mann-Whitney test was conducted to see whether there was a significantly different insulin pair with a pvalue of $<0.05$. The result can be found in the table below.

\section{Cost Analysis}

Based on the Kruskal-Wallis test, it was found that for type-2 DM outpatients at 
Medistra Hospital in 2012-2013, the discrimination test result for the medication cost between insulin types was 143.442 , the pvalue of 0.000 . Since the p-value was $0.000<$ $\alpha$ value $=0.05, \mathrm{H}_{0}$ hypothesis was rejected. This study showed a significant difference in the average treatment cost between insulin types (at least one significantly different insulin group).

Based on the Mann-Whitney cost test, there were four insignificantly different insulin pairs and 11 significantly different insulin pairs. The insulin pair is significantly different if the $p$-value was $<0.05$. The significant difference was when the use of insulin had a significant effect on medication cost.

The comparison between single-human insulin and single-analog insulin was not significantly different. The medication cost average of single-human insulin was around Rp3.190.997,43, while the single-analog insulin was slightly cheaper, which was around Rp3.188.832,15. The difference percentage of medication cost between single human insulin and analog insulin was $0.07 \%$. Although human insulin was cheaper than an analog one, the medication cost for human insulin was more expensive than analog insulin.

The comparison between humananalogue insulin and analogs insulin did not show a significant difference. The medication cost for human-analog insulin was Rp4.033.429,81, while analogs insulin was Rp3.924.517,01. The difference percentage between human-analog insulin and analogs insulin was $2.70 \%$.

Comparing the combination of human insulin-oral antidiabetic drugs (OAD) and the combination of analog insulin-OAD showed a significant difference. The medication cost for human insulin and OAD treatment was Rp3.241.515,46, while the cost for analog insulin and OAD treatment was Rp2.981.739,44. The difference percentage between human insulin-OAD and analog insulin-OAD was $8.01 \%$.

The result showed no significant difference between the medication cost for single human insulin and single analog insulin and the combination of human-analog insulin group and the variety of analogs insulin group. The result showed, however, that there was a significant difference in the medication cost for the human insulin-OAD and the analog insulin-OAD. This finding did not confirm the hypothesis stating that human insulin was cheaper compared to analog insulin.

\section{CONCLUSION}

Based on the research findings, it can be concluded that

1. Single-human insulin and analog insulin show a not significantly different result for the clinical outcome and medication cost.

2. The combination of human insulin-OAD and analog insulin-OAD shows an insignificant difference for the clinical outcome, yet a significant difference for the medication cost. The medication cost for analog insulin-OAD is cheaper than human insulin-OAD with a better clinical outcome.

3. The combination of analogs insulin and the combination of human-analog insulin shows a significantly different result for the fasting plasma glucose (FPG) clinical outcome. However, they show an insignificantly different result for the two-hour postprandial plasma glucose (2HPP) and HbA1c. Meanwhile, the medication cost shows an insignificantly different result. The combination of analogs shows a better FPG value than the combination of human-analog insulin.

\section{REFERENCES}

1. Ganong W. Buku Ajar Fisiologi Kedokteran. 11th ed. Jakarta: Buku Kedokteran EGC; 2013.

2. Soelistijo Soebagijo A NHE. Konsensus Pengelolaan dan Pencegahan Diabetes Mellitus Tipe 2 di Indonesia 2015. PB Perkeni; 2015.

3. Sanlioglu AD, Altunbas HA, Balci MK, Griffith TS SS. Clinical utility of insulin and insulin analogues. 2013; April:6778. 
4. Pusdatin Kementrian Kesehatan. Infodatin Diabetes Mellitus. 2014.

5. Organization WHO. Global Report on DM [Internet]. 2016. Available from: www.un.org.au

6. Ozougwu J C, Oimba KC, Belomwu CD UC. The Pathogenesis and Pathophysiology of Type-1 and Type- 2 Diabetes Mellitus. Acad J. 2013; 4:4657.

7. Pe M, Boltana A, Insa R, Soler J ME. Comparison of Human Insulin and Insulin Analogues on Hypoglycemia and Metabolic Variability in Type- 1 Diabetes Using Standardized Measurement (HYPO Score and Lability Index). Acta Diabetol. 2013;50(529-35).

8. PERKENI. Konsensus Pencegahan dan Pengelolaan Diabetes Mellitus Tipe 2 di Indonesia. Jakarta; 2015. 6-10, 14-51 p.

9. Wu Yan Ling, Yan Ping, Ding, Yoshimata Tanaka WZ. Risk Factors Contributing to Type-2 Diabetes and Recent in Treatment and Prevention. J Med Sci. 2014; 11: 1185-200.

10. PERKENI. Pengelolaan dan pencegahan diabetes melitus tipe 2 di Indonesia 2015. 2015.

11. Badan POM RI. Insulin. http://pionas.pom.go.id. 2015. p. Bab VI-Sistem Endokrin.

12. Tibaldi J. Evolution of Insulin: From Human to Analogue. Am J Med. 2014;127(10): S2.

13. Miriam TE. Why Are There No Generic Insulins? Medscape Medical News [Internet]. 2015; Available from www.medscape.com

14. Lepore M, Pampanelli S, Fanelli C, Porcellati F, Bartocci L, Vincentzo A Di et al. Pharmacokinetics and Pharmacodynamics of Subcutaneous Injection of Long-Acting Human Insulin Analogue Glargine, NPH Insulin and Ultralente Human Insulin and Continous Subcutaneous Infusion of Insulin Lispro. 2000;49.

15. Lipska L Kasia, Hirch Irlb RCM. Human Insulin for Type-2 Diabetes: An
Effective, Less-Expensive Option. Am Med Assoc. 2017; 23-4.

16. Hemkens LG, Grouven U, Bender R, Gunster C, Gutschmidt S SGW et al. Risk of Malignancies in Patients with Diabetes Treated with Human Insulin or Insulin Analogues: Cohort Study, Diabetologia. 2009;52(9) (1732-44).

17. Wu JW, Zoulay L, Majdan A, Boivin JF PMS. Long-Term Use of Long-Acting Insulin Analogues and Breast Incidence in Women with Type-2 Diabetes. J Clin Oncol. 2017.

18. Till S. Cancer Incidence Among Those Initiating Insulin Therapy with Glargine Versus Human NPH Insulin. 2013;36(3517-25).

19. Guillermo et. al. Insulin Analogue Versus Human Insulin in the Treatment of Patients with Diabetic Ketoacidosis. NCBI. 2009; 1164-9.

20. Holden S CC. Do the Benefits of Analogue Insulins Justify Their Cost? Future Med. 2012; 2(173-5).

21. Huo Jing MD. The Fair Price of Analogue Insulin When Compared Against Human Insulin: A Systematic Review of Published Cost-Effectiveness Studies and Mathematic Derivation of a Value-Based Formula. 2017.

22. Kompas. Pengobatan Diabetes Habiskan 33 Persen Biaya Kesehatan dari BPJS. Kompas Magazine. 2016.

23. G A. The Road to Free Insulin Guyana Case Study. Heal action Int Ovetoom. 2017.

24. Veronica WJ. Insulin Market Profile 2016. Department for Global Health and Development Boston University; 2016. $42 \mathrm{p}$.

25.American DA. Diagnosis and Classification of Diabetes Mellitus. Diabetes Care. 2010; 27:55.

26. Putri Nurlaili MI. Hubungan Empat Pilar Pengendalian BM Tipe 2 dengan Rerata Kadar Gula Darah. Berk Epidemiol. 2013;1(2):234-43.

27. Siebenhofer A. Short-Acting Insulin Analogueuages Versus Regular Human 
Insulin in Patients with Diabetes Mellitus. NCBI. 2004;1-3.

28. PERKENI. Petunjuk Praktis Terapi Insulin Pada Pasien Diabetes Mellitus. Jakarta; 2009. 7-8 p.

29. Huo J. Alternative Funding Sources to Improve Insulin Access: A Briefing Document for Low and Middle-Income Countries. Heal Action Int. 2017;(September):3-8.

30. Vannapruegs T, Hospital MT, Khunsri S. Thailand Case Study. Heal Action Int Overtoom [Internet]. 2017;60(20):4124523. Available from: www.haiweb.org

31. Abdraimova A. Aida Zurdinova Chief Pharmacologist Ministry of Health Kyryzstan Case Study. Heal Action Int Overtoom [Internet]. 2017;60(20):4124523. Available from: www.haiweb.org

32. Alarcon G. The Road to Free Insulin: Ecuador Case Study. Heal Action Int Overtoom [Internet]. 2017; 60(20):4124523. Available from: www.haiweb.org

33. Kementrian Kesehatan Republik Indonesia. Pedoman Penerapan Kajian Farmakoekonomi. 2013. 14 p.

34. Setiawan N. Penentuan Ukuran Sampel Memakai Rumus Slovin dan Tabel Krejcie Morgan: Telaah Konsep dan Aplikasinya. 2007.

35. Yosmar R, Almasdy D, Rahma F. Survei Risiko Penyakit Diabetes Melitus terhadap Kesehatan Masyarakat Kota Padang. J Sains Farm Dan Klin. 2018;5(Agustus 2018):134-41.

36. Yuhelma, Hasneli I Y, Annis N F. Identifikasi dan Analisis Komplikasi Makrovaskuler dan Mikrovaskuler pada Pasien Diabetes Mellitus. J Online Mhs. 2015; 2(1):569-79.

37. Santosa A, Trijayanto, Aji P, Endiyanto. Hubungan Riwayat Garis Keturunan dengan Usia Terdiagnosis Diabetes Melitus Tipe II. ISSN. 2017;1-6.

38. Kementerian Kesehatan Republik Indonesia. Riset Kesehatan Dasar 2018.

39. Suri MH, Haddani H, Sinulingga S, Studi $\mathrm{P}$, Dokter P, Kedokteran F, et al. Hubungan Karakteristik, Hiperglikemi, dan Kerusakan Saraf Pasien Neuropati
Diabetik di RSMH Palembang Neuropati diabetik merupakan komplikasi adalah lamanya menderita diabetes, Peningkatan usia menyebabkan kemampuan tubuh berkurang dalam meredam aktivitas. 2018; 4(1): 40-5.

40. Xie X, Liu Q, Wu J WM. Impact of cigarette smoking in type 2 diabetes development. 2009; 30(6) (784-7).

41. Redita M. Pengaruh Perilaku Merokok Terhadap Kadar Glukosa Darah: Tinjauan Lamanya merokok Pada Pria Merokok Bersuku Tionghoa Indonesia. 2017; 17.

42. Kusnanto K, Sundari PM, Asmoro CP, Arifin H. Hubungan Tingkat Pengetahuan dan Diabetes SelfManagement dengan Tingkat Stres Pasien Diabetes Melitus yang Menjalani Diet. J Keperawatan Indones. 2019;22(1): 31-42.

43. Firni Dwi Sari, Inayah MYH. Pola Penggunaan Obat Anti Hiperglikemik Oral pada Pasien Diabetes Melitus Tipe 2 Rawat Inap di Rumah Sakit X Pekanbaru Tahun 2014. Jom Fk. 2016; 3:1. 